\title{
A Study on Scientific Attitude of Elementary Teacher Education Students
}

\author{
P Vel Murugan* \\ Associate Professor, Bishop Agniswamy College of Education, India
}

Submission: February 23, 2019; Published: March 25, 2019

*Corresponding author: P Vel Murugan, Associate Professor in Education, Bishop Agniswamy College of Education, Muttom, Kanyakumari District, Tamil Nadu - 629 202, India

\begin{abstract}
The main objectives of this study are (i) to find out the significant difference between first year and second year, government and aided, rural and urban, nuclear family and joint family elementary teacher education students in their scientific attitude and (ii) to find out the significant association between father's education, mother's education, father's occupation, mother's occupation, order of birth, parent's annual income, and scientific attitude of elementary teacher education students. Scientific Attitude Scale (2014) developed by the investigator was used to collect the relevant data. The sample consists of 120 elementary teacher education students of whom 60 are from government institution and 60 are from government aided institutions. The data are analysed by percentage analysis, ' $\mathrm{t}$ ' test and chi-square test.

The result indicates that (i) there was no significant difference between first year and second year, government and aided, rural and urban, nuclear family and joint family elementary teacher education students in their scientific attitude, and (ii) there was no significant association between father's education, mother's education, father's occupation, mother's occupation, order of birth, parent's annual income, and scientific attitude of elementary teacher education students.
\end{abstract}

Keywords: Scientific attitude; Elementary Teacher, Education students.

\section{Introduction}

An attitude is a general and enduring positive or negative feeling about some person, object or issue [1]. Scientific attitudes are attributes of an individual who not only behaves outwardly in desirable way towards any scientific endeavour but also understands why they act as they do so [2]. According to National Society for the Study of Education (NSSE), "Scientific attitudes can be defined as open-mindedness, desire for accurate knowledge, confidence in procedures for seeking knowledge and the expectation that the solution of the problem will come through the use of verified knowledge". It is a mental attitude characterised by willingness to search for truth and prejudice to change one's opinion based on new evidence, to seek cause and affect relationships and to discriminate between fact and theory.

\section{Significance of the Study}

Attitude is essential for education of the individual because it shows the inner view of a person. If a person has a positive attitude towards an object, he will try his best to achieve it. If he has negative attitude towards an object, he will try to avoid it. Thus, attitude plays an important role in determining the success and failure of a person in any field [3]. Scientific attitude is a curiosity to know about one's environment; the belief that nothing can happen without a cause and those occurrences that seem strange and mysterious can always be explained by natural causes [4]. It is the possession of the skills and attitudes necessary for the usage of the scientific process and the possession of the knowledge acquired through the process that make a person a scientist [5]. Scientific attitudes are the most important outcomes of science teaching. Through science teaching certain social ethics and values such as honesty, rationality, objectivity and making judgement based on reliable information can be developed in our students. Therefore, a teacher plays the most important role in the development of scientific attitude among students. It's quite natural that if the elementary teacher education students have the scientific attitude, they would shine in his profession. So, the investigator probes to study the scientific attitude of elementary teacher education students.

\section{Review of Related Literature}

Ediger Marlow [6] studied the level of scientific attitude and scientific aptitude possessed by tenth class students of secondary schools. The findings revealed that the association between scientific attitude and scientific aptitude in both boys and girls, pupils studying in private and government schools, and pupils of urban and rural schools are highly significant. Vandana Punia 
\& Renu Bala [7] studied scientific attitude amongst the science and non-science pupil teachers: a comparative analysis. The findings revealed that there was no significant difference in the overall status of scientific attitude amongst science and nonscience pupil-teachers. Olasehinde \& Olatoye [8] studied scientific attitude, attitude to science and achievement in science at senior secondary level. The result shows that significantly positive correlation between attitude to science and scientific attitude, a non-significant positive correlation between scientific attitude and achievement in science and attitude to science and achievement in science. The boys and girls did not differ significantly from each other with respect to attitude to science, scientific attitude and achievement in science. Gokul Raj \& Malliga [9] studied scientific attitude among pre service teachers.

The findings revealed that there were significant differences in the level of scientific attitude among pre service teachers based on gender and subject group of the students and not significantly influenced by locality and age of the students. Manashee Gogoi \& Binoy Munda [8] studied scientific attitude of secondary school students of Sivasagar district in relation to their achievement in science. The findings revealed that there was a significant relationship between scientific attitude and achievement in science of students studying in secondary schools of Sivasagar district. Amit Ahuja [10] studied scientific attitude in relation to science achievement scores among secondary school students. The findings revealed that there was gender difference, in the favour of girl students with respect to scientific attitude and science achievement scores, and significantly positive correlation between scientific attitude and science achievement scores of students. Revati \& Meera [11] studied scientific attitude among secondary school students in Kottayam district of Kerala. The result shows that there was no significant difference in the scientific attitude of secondary school students based on gender, type of management and locale. From the studies reviewed, it is inferred that scientific attitude of elementary teacher education students has not been studied so far so deeply. So, the investigator selects the topic "scientific attitude of elementary teacher education students".

\section{Statement of the Problem}

The problem of the study is precisely stated below.

"A Study on Scientific Attitude of Elementary Teacher Education Students"

\section{Objectives}

i. To find out the level of scientific attitude of elementary teacher education students.

ii. To find out whether there is any significant difference between (a) first year and second year, (n) government and aided, (c) rural and urban, (d) nuclear family and joint family elementary teacher education students in their scientific attitude. iii. To find out whether there is any significant association between father's education, mother's education, father's occupation, mother's occupation, order of birth, parent's annual income, and scientific attitude of elementary teacher education students.

\section{Null Hypotheses}

i. There is no significant difference between (a) first year and second year, (b) government and aided, (c) rural and urban, (d) nuclear family and joint family elementary teacher education students in their scientific attitude.

ii. There is no significant association between father's education, mother's education, father's occupation, mother's occupation, order of birth, parent's annual income, and scientific attitude of elementary teacher education students.

\section{Methodology}

The investigator adopted survey method. The population for the study is elementary teacher education students in Kanyakumari district, Tamil Nadu. The investigator has used simple random sampling technique for collecting the data. The sample consists of 120 elementary teacher education students. Among them 60 are from government institution and 60 are from government aided institutions. Scientific Attitude Scale (2014) developed by the investigator was used for collecting the data. Percentage analysis, ' $t$ ' test and chi-square test were used to analyse the data.

\section{Description of the Tool}

The tool contains 42 items. In each item there are five alternatives representing the five possible ways. They are strongly agree, agree, neutral, disagree, and strongly disagree. The respondent can choose one of the alternatives for each item and put a tick mark on the column. Each marking has a value to be counted. The item carries the weights of 5, 4, 3, 2, and 1 for the categories of strongly agree, agree, neutral, disagree, and strongly disagree respectively. The total score is the summation of all the items.

\section{Establishing Validity and Reliability of the Tool}

The researcher has established content validity for the tool. The researcher has used split-half method for establishing reliability of the tool. The product moment correlation coefficient was computed between the scores in odd and even number items. It is found to be 0.79 . Thus, the reliability of the tool has been established.

\section{Analysis of Data}

Table 1: Level of Scientific Attitude of Elementary Teacher Education Students.

\begin{tabular}{|c|c|c|c|c|c|c|}
\hline \multirow{2}{*}{ Variable } & \multicolumn{2}{|c|}{ Low } & \multicolumn{2}{c|}{ Moderate } & \multicolumn{2}{c|}{ High } \\
\cline { 2 - 7 } & No. & $\%$ & No. & $\%$ & No. & $\%$ \\
\hline Scientific Attitude & 18 & 15.0 & 84 & 70.0 & 18 & 15.0 \\
\hline
\end{tabular}


(Table 1) It is inferred from the above table that $15.0 \%$ of elementary teacher education students have low, $70.0 \%$ of them have moderate and $15.0 \%$ of them have high level of scientific attitude.

(Table 2) It is inferred from the table that $8.3 \%$ of elementary teacher education students from first year have low, $75.0 \%$ of them have moderate and $16.7 \%$ of them have high level of scientific attitude, whereas $21.7 \%$ of elementary teacher education students from second year have low, $65.0 \%$ of them have moderate and $13.3 \%$ of them have high level of scientific attitude. It is understood from the table that $10.0 \%$ of elementary teacher education students from government institution have low, $73.3 \%$ of them have moderate and $16.7 \%$ of them have high level of scientific attitude, whereas $20.0 \%$ of elementary teacher education students from aided institutions have low, $66.7 \%$ of them have moderate and $13.3 \%$ of them have high level of scientific attitude.

Table 2: Level of Scientific Attitude of Elementary Teacher Education Students with Reference to Background Variables.

\begin{tabular}{|c|c|c|c|c|c|c|c|}
\hline \multirow{2}{*}{\multicolumn{2}{|c|}{ Demographic Variables }} & \multicolumn{2}{|c|}{ Low } & \multicolumn{2}{|c|}{ Moderate } & \multicolumn{2}{|c|}{ High } \\
\hline & & No. & $\%$ & No. & $\%$ & No. & $\%$ \\
\hline \multirow{2}{*}{ Year of Study } & First & 5 & 8.3 & 45 & 75.0 & 10 & 16.7 \\
\hline & Second & 13 & 21.7 & 39 & 65.0 & 8 & 13.3 \\
\hline \multirow{2}{*}{ Type of Institution } & Government & 6 & 10.0 & 44 & 73.3 & 10 & 16.7 \\
\hline & Aided & 12 & 20.0 & 40 & 66.7 & 8 & 13.3 \\
\hline \multirow{2}{*}{ Locality of Home } & Rural & 11 & 14.3 & 55 & 71.4 & 11 & 14.3 \\
\hline & Urban & 7 & 16.3 & 29 & 67.4 & 7 & 16.3 \\
\hline \multirow{2}{*}{ Type of Family } & Nuclear & 16 & 14.7 & 79 & 72.5 & 14 & 12.8 \\
\hline & Joint & 2 & 18.2 & 5 & 45.5 & 4 & 36.4 \\
\hline \multirow{4}{*}{ Father's Education } & Illiterate & 15 & 16.1 & 65 & 69.9 & 13 & 14.0 \\
\hline & School Education & 2 & 10.0 & 14 & 70.0 & 4 & 20.0 \\
\hline & College Education & 1 & 14.3 & 5 & 71.4 & 1 & 14.3 \\
\hline & Professional Education & 0 & 0 & 0 & 0 & 0 & 0 \\
\hline \multirow{4}{*}{ Mother's Education } & Illiterate & 9 & 22.0 & 28 & 68.3 & 4 & 9.8 \\
\hline & School Education & 6 & 10.9 & 40 & 72.7 & 9 & 16.4 \\
\hline & College Education & 3 & 12.5 & 16 & 66.7 & 5 & 20.8 \\
\hline & Professional Education & 0 & 0 & 0 & 0 & 0 & 0 \\
\hline \multirow{4}{*}{ Father's Occupation } & Unemployed & 1 & 10.0 & 7 & 70.0 & 2 & 20.0 \\
\hline & Coolie & 17 & 17.2 & 69 & 69.7 & 13 & 13.1 \\
\hline & Private Company & 0 & 0 & 6 & 66.7 & 3 & 33.3 \\
\hline & Government Employee & 0 & 0 & 2 & 100.0 & 0 & 0 \\
\hline \multirow{4}{*}{ Mother's Occupation } & Home maker & 12 & 16.0 & 52 & 69.3 & 11 & 14.7 \\
\hline & Coolie & 5 & 13.5 & 27 & 73.0 & 5 & 13.5 \\
\hline & Private Company & 1 & 14.3 & 5 & 71.4 & 1 & 14.3 \\
\hline & Government Employee & 0 & 0 & 0 & 0 & 1 & 100.0 \\
\hline \multirow{3}{*}{ Order of Birth } & First & 6 & 10.9 & 40 & 72.7 & 9 & 16.4 \\
\hline & Second & 9 & 19.6 & 31 & 67.4 & 6 & 13.0 \\
\hline & Third and above & 3 & 15.8 & 13 & 68.4 & 3 & 15.8 \\
\hline \multirow{3}{*}{ Parents Annual Income } & Below Rs. 50,000 & 15 & 14.7 & 70 & 68.6 & 17 & 16.7 \\
\hline & Between Rs. 50,000 and Rs. $1,00,000$ & 3 & 18.8 & 13 & 81.3 & 0 & 0 \\
\hline & Above Rs. $1,00,000$ & 0 & 0 & 1 & 50.0 & 1 & 50.0 \\
\hline
\end{tabular}

The table shows that $14.3 \%$ of elementary teacher education students from rural area have low, $71.4 \%$ of them have moderate and $14.3 \%$ of them have high level of scientific attitude, whereas $16.3 \%$ of elementary teacher education students from urban area have low, $67.4 \%$ of them have moderate and $16.3 \%$ of them have high level of scientific attitude. It is inferred from the table that $14.7 \%$ of elementary teacher education students from nuclear family have low, $72.5 \%$ of them have moderate and $12.8 \%$ of them have high level of scientific attitude, whereas $18.2 \%$ of elementary teacher education students from joint family have low, $45.5 \%$ of them have moderate and $36.4 \%$ of them have high level of scientific attitude.

It is inferred from the above table, based on the illiteracy of the fathers of elementary teacher education students, $16.1 \%$ of 
them are found at the low level, $69.9 \%$ of them are at moderate level and $14 \%$ of them are at high level with scientific attitude. It is understood from the table, based on the school education of the fathers of elementary teacher education students, $10 \%$ of them are found at the low level, $70 \%$ of them are at moderate level and $20 \%$ of them are at high level with scientific attitude. It is known from the table, on the basis of the college education of the fathers of elementary teacher education students, $14.3 \%$ of them are found at the low level, $71.4 \%$ of them are at moderate level and $14.3 \%$ of them are at high level with scientific attitude. It is clearly understood from the table, based on the professional education of the fathers of elementary teacher education students, none of them are found at low, moderate and high level with scientific attitude.

It is inferred from the above table, based on the illiteracy of the mothers of elementary teacher education students, $22 \%$ of them are found at the low level, $68.3 \%$ of them are at moderate level and $9.8 \%$ of them are at high level with scientific attitude. It is understood from the table, on the basis of the school education of the mothers of elementary teacher education students, $10.9 \%$ of them are at the low level, $72.7 \%$ of them are at moderate level and $16.4 \%$ of them are at high level with scientific attitude. It is known from the table, on the basis of the college education of the mothers of elementary teacher education students, $12.5 \%$ of them are at the low level, $66.7 \%$ of them are at moderate level and $20.8 \%$ of them are at high level with scientific attitude. It is clearly understood from the table, on the basis of the professional education of the mothers of elementary teacher education students, none of them are low, moderate and high level with scientific attitude.

It is inferred from the above table, on the basis of unemployed fathers of the elementary teacher education students, $10 \%$ of them are found at the low level, $70 \%$ of them are at moderate level and $20 \%$ of them are at high level with scientific attitude. It is understood from the table, on the basis of daily wage-earners (coolies) fathers of elementary teacher education students, $17.2 \%$ of them are found at the low level, $69.7 \%$ of them are at moderate level and $13.1 \%$ of them are at high level with scientific attitude. It is known from the table, on the basis of the fathers of elementary teacher education students who are employed in private companies, none of them are found at the low level, $66.7 \%$ of them are at moderate level and $33.3 \%$ of them are at high level with scientific attitude. It is clearly understood from the table, on the basis of the fathers of elementary teacher education students who are in the employ of government, none of them are found at the low level, $100 \%$ of them are at moderate level and none of them are at high level with scientific attitude.

It is inferred from the above table, on the basis of the mothers of the elementary teacher education students who are home makers, $16 \%$ of them are found at the low level, $69.3 \%$ of them are at moderate level and $14.7 \%$ of them are at high level with scientific attitude. It is understood from the table, on the basis of daily wage-earners (coolies) mothers of elementary teacher education students, $13.5 \%$ of them are found at low level, $73 \%$ of them are at moderate level and $13.5 \%$ of them are at high level with scientific attitude. It is known from the table, on the basis of the mothers of elementary teacher education students who are employed in private companies, $14.3 \%$ of them are found at the low level, $71.4 \%$ of them are at moderate level and $14.3 \%$ of them are at high level with scientific attitude. It is clearly understood from the table, on the basis of the mothers of elementary teacher education students who are in the employ of government, none of them are found at low and moderate level, and $100 \%$ of them are at high level with scientific attitude.

It is inferred from the above table, on the basis of the first born elementary teacher education students, $10.9 \%$ of them are found at the low level, $72.7 \%$ of them are at moderate level and $16.4 \%$ of them are at high level with scientific attitude. It is understood from the table, based on the second born elementary teacher education students, $19.6 \%$ of them are found at the low level, $67.4 \%$ of them are at moderate level and $13 \%$ of them are at high level with scientific attitude. It is known from the table, on the basis of the third and above born elementary teacher education students, $15.8 \%$ of them are found at the low level, $68.4 \%$ of them are at moderate level and $15.8 \%$ of them are at high level with scientific attitude.

It is inferred from the above table, on the basis of the annual income of parents getting annual income below Rs.50,000 of elementary teacher education students, $14.7 \%$ of them are found at the low level, $68.6 \%$ of them are at moderate level and $16.7 \%$ of them are at high level with scientific attitude. It is understood from the table, on the basis of the annual income of parents getting annual income between Rs.50,000 and Rs.1,00,000 of elementary teacher education students, $18.8 \%$ of them are found at the low level, $81.3 \%$ of them are at moderate level and none of them are at high level with scientific attitude. It is known from the table, on the basis of the annual income of parents getting annual income above Rs.1,00,000 of elementary teacher education students, none of them are found at the low level, $50 \%$ of them are at moderate level and $50 \%$ of them are at high level with scientific attitude.

\section{Null Hypothesis 1}

There is no significant difference between (i) first year and second year, (ii) government and aided, (iii) rural and urban, (iv) nuclear family and joint family elementary teacher education students in their scientific attitude.

(Table 3) It is inferred from the above table that there is no significant difference between first year and second year elementary teacher education students in their scientific attitude. It is understood from the table that there is no significant difference between elementary teacher education students from government and aided institutions in their scientific attitude. It is known from the table that there is no significant difference between elementary teacher education students from rural and 


\section{Psychology and Behavioral Science International Journal}

urban area in their scientific attitude. It is clearly understood from the table that there is no significant difference between

Table 3: Difference in Scientific Attitude of Elementary Teacher Education Students with Reference to Background Variables.

\begin{tabular}{|c|c|c|c|c|c|c|}
\hline Background Variables & Category & Count & Mean & S.D & Calculated value of ' $t$ ' & Remarks at $5 \%$ level \\
\hline \multirow{2}{*}{ Year of Study } & First & 60 & 153.53 & 14.784 & 1.288 & Not Significant \\
\hline & Second & 60 & 149.83 & 16.631 & & \\
\hline \multirow{2}{*}{ Type of Institution } & Government & 60 & 153.60 & 16.006 & 1.335 & Not Significant \\
\hline & Aided & 60 & 149.77 & 15.442 & & \\
\hline \multirow{2}{*}{ Locality of Home } & Rural & 77 & 152.14 & 15.857 & 0.426 & Not Significant \\
\hline & Urban & 43 & 150.86 & 15.788 & & \\
\hline \multirow{2}{*}{ Type of Family } & Nuclear & 109 & 151.33 & 15.109 & 0.568 & Not Significant \\
\hline & Joint & 11 & 155.18 & 21.958 & & \\
\hline
\end{tabular}

(At $5 \%$ level of significance, the table value of ' $t$ ' is 1.98)

\section{Null Hypothesis 2}

There is no significant association between father's education, mother's education, father's occupation, mother's occupation, order of birth, parent's annual income, and scientific attitude of elementary teacher education students.

(Table 4) It is inferred from the above table that there is no significant association between fathers' education and scientific attitude of elementary teacher education students. It is understood from the table that there is no significant association between mothers' education and scientific attitude of elementary elementary teacher education students from nuclear family and joint family in their scientific attitude.
Table 4: Association between Scientific Attitude of Elementary Teacher Education Students with Reference to Background Variables.

\begin{tabular}{|c|c|c|c|c|}
\hline Background Variables & df & Calculated value of ' $\chi 2$ ' & Table Value & Remarks at $5 \%$ level \\
\hline Father's Education & 4 & 0.817 & 9.488 & Not Significant \\
\hline Mother's Education & 4 & 3.512 & 9.488 & Not Significant \\
\hline Father's Occupation & 6 & 5.114 & 12.592 & Not Significant \\
\hline Mother's Occupation & 6 & 5.890 & 12.592 & Not Significant \\
\hline Order of Birth & 4 & 1.564 & 9.488 & Not Significant \\
\hline Parent's Annual Income & 4 & 5.109 & 9.488 & Not Significant \\
\hline
\end{tabular}

\section{Findings}

i. $\quad 15.0 \%$ of elementary teacher education students have high level of scientific attitude.

ii. $\quad 16.7 \%$ of first year and $13.3 \%$ of second year elementary teacher education students have high level of scientific attitude.

iii. $\quad 16.7 \%$ of elementary teacher education students from government institution and $13.3 \%$ of elementary teacher education students from aided institutions have high level of scientific attitude.

iv. $14.3 \%$ of elementary teacher education students from rural area and $16.3 \%$ of elementary teacher education students from urban area have high level of scientific attitude.

v. $12.8 \%$ of elementary teacher education students from nuclear family and $36.4 \%$ of elementary teacher education students from joint family have high level of scientific attitude. teacher education students. It is known from the table that there is no significant association between fathers' occupation and scientific attitude of elementary teacher education students. It is clearly understood from the table that there is no significant association between mothers' occupation and scientific attitude of elementary teacher education students. The table shows that there is no significant association between order of birth and scientific attitude of elementary teacher education students. The table reveals that there is no significant association between parent's annual income and scientific attitude of elementary teacher education students. vi. There is no significant difference between first year and second year elementary teacher education students in their scientific attitude.

vii. There is no significant difference between elementary teacher education students from government and aided institutions in their scientific attitude.

viii. There is no significant difference between elementary teacher education students from rural and urban area in their scientific attitude.

ix. There is no significant difference between elementary teacher education students from nuclear family and joint family in their scientific attitude.

$\mathrm{x}$. There is no significant association between father's education and scientific attitude of elementary teacher education students.

xi. There is no significant association between mother's 
education and scientific attitude of elementary teacher education students.

xii. There is no significant association between father's occupation and scientific attitude of elementary teacher education students.

xiii. There is no significant association between mother's occupation and scientific attitude of elementary teacher education students.

xiv. There is no significant association between order of birth and scientific attitude of elementary teacher education students.

xv. There is no significant association between parent's annual income and scientific attitude of elementary teacher education students.

\section{Recommendations}

i. Awareness programme should be conducted to the student teachers on different dimensions of scientific strategies.

ii. Innovative teaching strategies should be incorporated to develop scientific knowledge and regulation.

iii. Curriculum may be modified in such a way that we can improve all the dimensions of scientific domain.

iv. Discussion, debate, workshops and seminars be conducted to develop the scientific attitude.

\section{Discussion and Conclusion}

It is inferred from the findings that there is no significant difference between first year and second year, government and aided institutions, rural and urban area, and nuclear family and joint family elementary teacher education students. This may be due to the fact that the objectives of the present curriculum inbuilt the student's scientific attitude. This is supported by the study of Gokul Raj Malliga [8] which reveals that the scientific attitude among pre-service teachers is not significantly influenced by locality. The study of Revati \& Meera [11] also supported the findings which reveal that there is no significant difference in the



is work is licensed under Creative Commons Attribution 4.0 License DOI: 10.19080/PBSIJ.2019.11.555805 scientific attitude of secondary school students based on type of management and locale.

It is understood from the findings that there is no significant association between father's education, mother's education, father's occupation, mother's occupation, order of birth, parent's annual income, and scientific attitude of elementary teacher education students. This may be due to the fact that the external factors do not influence to develop the scientific attitude among the students because the students acquire knowledge of science from their curriculum. Therefore, the students develop their scientific attitude through science teaching.

\section{References}

1. Jones B, Batts B (1983) Development of set of scales to measure selected scientific attitude. Research in Science Education, 13(1): 133-140.

2. Rao DB (1996) Scientific Attitude vis-a-vis Scientific Aptitude. In: Discovery Publishing House, New Delhi, India.

3. Vandana Punia, Renu Bala (2009) Scientific attitude amongst the science and non-science pupil teachers: a comparative analysis.

4. Caldwell OW, Curtis FD (1943) Everyone science. Boston: Ginn and Co.

5. Opong I K (1981) Science education in primary schools: Toe product of science or the way to science. Journal of Science Teachers Association of Nigeria 19(2): 9-17.

6. Ediger Marlow (2006) Scientific attitude and scientific aptitude. In: Progress Publication, Moscow

7. Olasehinde KJ, Olatoye RA (2014) Scientific attitude, attitude to science and science achievement of senior secondary school students in Katsina State Nigeria. J Edu Soc Res 4(1): 445-452.

8. Gokul Raj R, Malliga T (2015) A study on scientific attitude among pre service teachers. Research Journal of Recent Sciences 4: 196-198.

9. Manashee Gogoi, Binoy Munda (2016) Scientific attitude of secondary school students of Sivasagar district in relation to their achievement in science. International Journal of Innovation Sciences and Research 5(02): 637-641.

10. Amit Ahuja (2017) Study of scientific attitude in relation to science achievement scores among secondary school students. Educational Quest: An International Journal of Education and Applied Social Science 8(1): 9-16.

11. Revati N, Meera KP (2017) An investigation of scientific attitude among secondary school students in Kottayam district of Kerala. IOSR Journal of Research \& Method in Education 7(1): 63-66.

\section{Your next submission with Juniper Publishers will reach you the below assets}

- Quality Editorial service

- Swift Peer Review

- Reprints availability

- E-prints Service

- Manuscript Podcast for convenient understanding

- Global attainment for your research

- Manuscript accessibility in different formats

( Pdf, E-pub, Full Text, Audio)

- Unceasing customer service

Track the below URL for one-step submission https://juniperpublishers.com/online-submission.php 